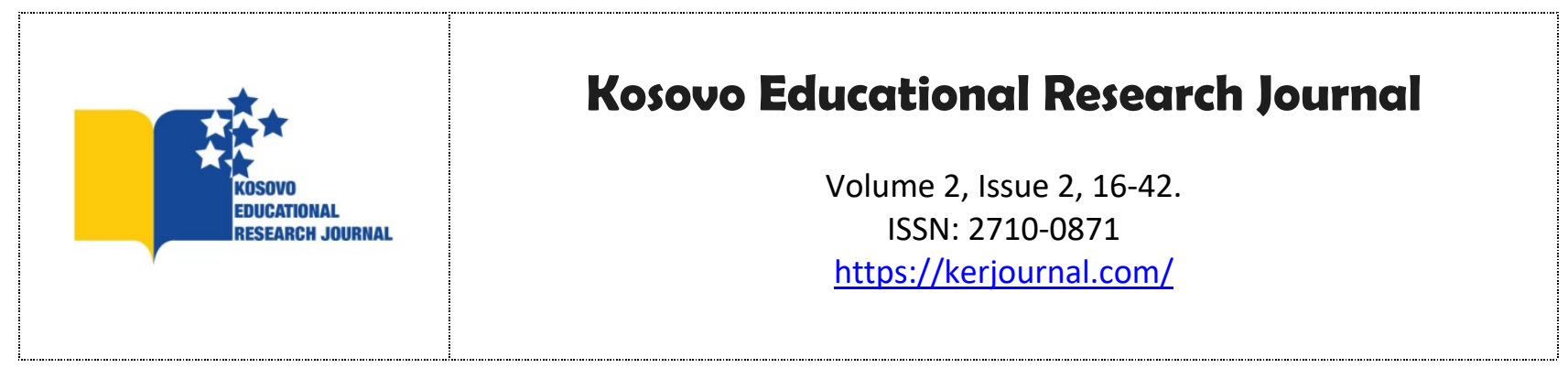

\title{
Türkiye’de Öğretmenlik Meslek Kanunu Tasarılarının İncelenmesi
}

\author{
Cem TUNA $^{1} \quad$ Yakub KAZDAL $^{2}$
}

\begin{abstract}
Özet: Milli eğitim sisteminin en önemli paydaşlarından biri olan öğretmenler bir meslek kanuna ihtiyaç duymaktadır. Öğretmenlik mesleğiyle ilgili şu ana kadar yapılmış kanuni düzenlemeler dağınık bir görüntü vermekte ve yetersiz kalmaktadır. Uzmanlığın öneminin giderek arttığı günümüzde öğretmenlerin görevlerinin, sorumluluklarının ve haklarının tek bir yasal metin içinde günümüz şartları da gözetilerek yeniden düzenlenmesi önem arz etmektedir.

MEB 2023 Eğitim Vizyonu belgesinde öğretmenler için bir meslek kanunu hazırlı̆̆ yapılacağı ifade edilmiştir. Hazırlanacak meslek kanunu için kurum, dernek ve sendikalardan farklı ortamlarda olmak üzere tasarı, teklif ve öneriler gelmeye başlamıştır. Bu çalışmada önerilerden dört tanesi üzerinde karşılaştırmalı olarak durulmuştur. Bunlar TEDMEM'in hazırladığı "Öğretmenlik Meslek Kanunu Öneri Metni", EğitimBir-Sen'in hazırladığı "Öğretmenlik Meslek Kanunu İhtiyaçlar Öneriler", Şuurlu Öğretmenler Derneği’nin "Öğretmenlik Meslek Kanunu Hakkındaki Düşünceler" ve CHP’nin 2018 yılı "Öğretmenlik Meslek Kanunu Teklifi" isimli metinlerdir. Çalışmada ulaşılan ortak sonuçlardan bir kaçı şöyledir: Öğretmenlik, profesyonel bir meslektir. Öğretmenlik Meslek Kanunu paydaşlar için bir ihtiyaçtır. Mesleki standartlar belirlenmiş olmalıdır. Öğretmen adayları yükseköğretim programlarında yetiştirilir. Öğretmen adaylarının yetiştirilmesinde uygulamaya önem verilir. Öğretmenler kadrolu olarak atanmalıdır. Öğretmen adayları öğretmenliğe alınırken sınava tabi tutulmalıdır. Kariyer basamaklarında yükselmeler nesnel ölçütlere dayanmalıdır. Öğretmenler, dezavantajlı çalışma şartları gözetilerek ücret almalıdır. Öğretmenlere karşı işlenen suçların cezaları ağırlaştırılarak verilmelidir.
\end{abstract}

Anahtar Kelimeler: Türkiye, Öğretmenlik Mesleği, Sivil Toplum Kuruluşları, Kanun Tasarıları To cite this article: Tuna, C. \& Kazdal, Y. (2021). Türkiye'de Öğretmenlik Meslek Kanunu Tasarılarının İncelenmesi. Kosovo Educational Research Journal, 2(2), 16-42

\section{Examining the Draft Law on the Teaching Profession in Turkey}

\begin{abstract}
Teachers, one of the most important stakeholders of the national education system, need a professional law. The legal regulations made so far regarding the teaching profession give a messy
\end{abstract}

\footnotetext{
${ }^{1}$ Recep Tayyip Erdoğan Üniversitesi, Eğitim Fakültesi, Eğitim Bilimleri Bölümü, 53200 Çayeli-RİZE. cem.topsakal@erdogan.edu.tr, ORCID: 0000-0002-6846-8676

${ }^{2}$ RTEÜ Sosyal Bilimler Enstitüsü Eğitim Bilimleri Anabilim Dalı öğrencisi
} 
appearance and remain insufficient. It is important to reorganize the duties, responsibilities and rights of teachers in a single legal text, taking into account today's conditions.

In the MEB 2023 Education Vision document, it is stated that a professional law will be prepared for teachers. Drafts, proposals and proposals have started to come from institutions, associations and unions, in different environments, for the occupational law to be prepared. In this study, four of the suggestions were comparatively emphasized. These are the "Teaching Profession Law Suggestion Text" prepared by TEDMEM, "Teaching Profession Law Needs and Suggestions" prepared by Eğitim-Bir-Sen, "Thoughts on the Teaching Profession Law" by the Conscious Teachers Association and the CHP's 2018 "Teaching Profession Law". Law Proposal". Some of the common results reached in the study are as follows: Teaching is a professional profession. The Teaching Profession Law is a need for stakeholders. Professional standards must be established. Teacher candidates are trained in higher education programs. Practice is given importance in the training of teacher candidates. Teachers should be appointed on a permanent basis. Candidate teachers must be tested while being admitted to teaching. Promotions in the career ladder should be based on objective criteria. Teachers should be paid by considering the disadvantaged working conditions. Penalties for crimes against teachers should be given aggravated.

Keywords: Turkey, Teaching Profession, Non-Governmental Organizations, Draft Laws

\section{GİRİS}

Türk Eğitim Sistemi’nde yasalara göre öğretmenlik, Devletin eğitim, öğretim ve bununla ilgili yönetim görevlerini üzerine alan özel bir ihtisas mesleğidir. Öğretmenler bu görevlerini Türk milli eğitiminin amaçlarına ve temel ilkelerine uygun olarak yerine getirmekle yükümlüdürler (Tuna, 2021, 99). Öğretmenlik mesleğine hazırlık genel kültür, özel alan eğitimi ve pedagojik formasyon ile sağlanır (Sarpkaya, 2004, 67-68). Öğretmenlik; bireysel, sosyal, kültürel, bilimsel, teknolojik boyutlu profesyonel statüde bir eğitim mesleğidir (Titrek, 2006, 311).

Meslek; belli bir eğitim ile kazanılan, sistemli bilgi ve becerilere dayalı, insanlara yararlı mal üretmek, hizmet vermek ve karşılığında para kazanmak için yapılan, kuralları belirlenmiş iştir (Tük Dil Kurumu , 2020). Bu tanımdan; öğretmen olabilmek için diploma/sertifikaya sahip olmak, uzmanlık gösterebilmek, öğrencilere eğitim ve öğretim hizmeti vermek, ücret almak, mevzuata sahip olmak çıkarımları yapılabildiğine göre öğretmenlik bir meslektir.

Profesyonel anlamda meslek sahipleri kanunlarla görev ve sorumluluklarını yerine getirirler ve bazı haklara sahip olurlar. Bazı meslek sahiplerinin -3458 Sayılı Mühendislik ve Mimarlık Hakkında Kanun, 1136 Sayılı Avukatlık Kanunu vb.- meslek kanunları vardır. Öğretmenler bir 
meslek kanununa sahip değillerdir. Öğretmenlik mesleğiyle ilgili düzenlemeler farklı kanunlarda ifade edilmiştir.

Dünya'da birçok ülkede öğretmenlik mesleğiyle ilgili kanunlar bulunmaktadır. İngiltere, Almanya, Kanada, Çin ve Avustralya gibi ülkeler öğretmenlik meslek kanunu olan ülkelere örnek gösterilebilir (TEDMEM).

Uluslararası alanda öğretmenlik meslek kanunu için bazı sendikalar tarafından referans gösterilen Öğretmenlerin Statü Tavsiyesi, ilk ve orta öğretim personelinin statüsünü tüm yönleriyle düzenleme amacıyla Uluslararası Çalışma Örgütü (ILO) ile UNESCO'nun, kendi sorumluluk ve uzmanlık alanlarına giren sorunlar konusundaki sıkı işbirliğinin bir ürünü olarak ortaya çıkmıştır.

ILO ve UNESCO, üye devletlere öğretmenlerle ilgili tüm sorunları ele alan bir belgenin kabul edilmesi önerisinde bulunmuş ve ortaklaşa yürüttükleri uzun çalışmalar sonunda, Paris’te hükümetler arası özel bir konferans toplanmıştır. UNESCO'ca toplantıya çağrılan bu konferansta, devletlerin ve öğretmen örgütlerinin gözlem ve görüşleri göz önüne alınarak, ILOUNESCO ortak uzmanlar toplantısında hazırlanan bir Tavsiye Tasarısı incelenmiş ve kimi değişikliklerden sonra 5 Ekim 1966 tarihinde oybirliğiyle kabul edilmiştir (Gülmez, 2010).

Öğretmenlerin Statü Tavsiyesi öğretmenlik mesleğine hazırlama, öğretmenlerin yetiştirilmesi, istihdam ve kariyer, öğretmenlerin hakları ve ödevleri vb. birçok konuda ilkeler koymakta, öneriler getirmektedir.

Milli Eğitim Bakanlığı 3 Ağustos 2016 tarihli Yönetmelikle sözleşmeli ögrretmen sistemine geçmiştir (MEB, 2016; Topsakal, 2019). Bu Yönetmeliğin amacı, öncelikle kalkınmada birinci derecede öncelikli yörelerde olmak üzere öğretmen istihdamına ilişkin usul ve esasları belirlemektir (MEB, 2016, Madde 1).

Milli Eğitim Bakanlığı (MEB) 2023 Eğitim Vizyonunda “Öğretmen ve okul yöneticilerimizin atanmaları, çalışma şartları, görevde yükselmeleri, özlük hakları ve benzeri diğer hususları dikkate alan Öğretmenlik Meslek Kanunu çıkarılmasına ilişkin hazırlık çalışmaları yürütülecektir” (MEB, 2020, 10) ifade edildikten sonra, öğretmenlik meslek kanununun çıkarılması gerektiği konusunda paydaşlar arası bir mutabakat söz konusu olduğu görülmüş̧ür.

$\mathrm{Bu}$ çalışmada inceleme konusu yapılan metinlerden biri TEDMEM'in “Öğretmenlik Meslek Kanunu Öneri metnidir. "Genel Gerekçe” başlı̆̆ı altında kapsayıcı bir değerlendirmenin 
yapıldığ 1 bölüm öneri metninin giriş kısmını oluşturmaktadır. Ardından gerekçeleriyle birlikte 26 madde sıralanmıştır.

İnceleme konusu yapılan diğer metin ise "Öğretmenlik Meslek Kanunu İhtiyaçlar Öneriler" ismini taşımaktadır. Eğitim-Bir-Sen tarafından hazırlanan bu metnin girişinde "Öğretmenlik Meslek Kanunu İhtiyacı” başlığı bulunmakta, öneriler TEDMEM'deki gibi kanun formatında değil kısa, genel ifadelerle aktarılmaktadır.

Şuurlu Öğretmenler Derneği (ÖĞ-DER) tarafından hazırlanan 'Öğretmenlik Meslek Kanunu Hakkındaki Düşünceler' adlı metinde; kanunun nelerden oluşması, neleri kapsaması üzerinde durulmuştur.

Cumhuriyet Halk Partisi (CHP) Ankara Milletvekili Yıldırım Kaya tarafindan hazırlanan Öğretmenlik Meslek Kanununa ilişskin Kanun Teklifi’nde ise öğretmenlik, eğitim yöneticiliği ve eğitim müfettişliği hakları, görev ve sorumlulukları detaylı olarak ortaya konulmuştur.

\section{Amaç}

$\mathrm{Bu}$ çalışmanın amacı, Türkiye'de sivil toplum kuruluşları ve siyasi partilerin hazırladığ öğretmenlik meslek kanunu tasarılarının incelenmesidir. Bu konuda dört metin karşılaştırmalı olarak incelenmiş, ortak noktalar tespit edilmeye çalışılmıştır.

$\mathrm{Bu}$ amaca dayalı olarak Türkiye'de sivil toplum kuruluşları ve siyasi partilerin öğretmenlik meslek kanunu tasarıları ile ilgili aşağıdaki sorulara cevap aranmıştır:

1. Türkiye'de öğretmenlik meslek kanunu tasarılarının genel gerekçesi nedir?

2. Türkiye'de öğretmenlik meslek kanunu tasarılarının amaç ve kapsamı nedir?

3. Türkiye'de öğretmenlik meslek kanunu tasarılarında görevler, haklar ve sorumluluklar nelerdir?

4. Türkiye'de öğretmenlik meslek kanunu tasarılarında öğretmen yetiştirme, atama, yer değiştirme ve nakil nasıl düzenlenmiştir?

5. Türkiye'de öğretmenlik meslek kanunu tasarılarında eğitim yöneticiliği ve milli eğitim müfettişliği nasıl düzenlenmiştir?

6. Öğretmenlerin mesleki faaliyetlerinin izlenmesi, değerlendirilmesi ve mesleki gelişimin sağlanması nasıl düzenlenmiştir?

7. Eğitim çalışanlarının özlük hakları nasıl düzenlenmiştir?

8. Mesleki ve etik davranış standartları nasıl düzenlenmiştir?

9. Disiplin işleri nasıl düzenlenmiştir? 


\section{Yöntem}

Çalışma, genel tarama modellerinden doküman incelemesine dayalıdır. Doküman incelemesinde temel amaç, araştırılması istenen olgu ya da olgular hakkında bilgi içeren yazılı materyallerin analizidir (Yıldırım ve Şimşek, 2006; Büyüköztürk, Kılıç Çakmak, Akgün, Karadeniz ve Demirel, 2013). Doküman incelemesi beş aşamada yapılabilmektedir:

1. Dokümanlara ulaşılması, 2. Orijinal olup olmamanın kontrol edilmesi, 3. Dokümanların anlaşılması, 4. Verilerin analizi ve 5. Verilerin araştırmada kullanılması.

Bu çalışmada Türkiye'de TEDMEM'in hazırladığı "Öğretmenlik Meslek Kanunu Öneri Metni", Eğitim-Bir-Sen'in hazırladığı "Öğretmenlik Meslek Kanunu İhtiyaçlar Öneriler", Şuurlu Öğretmenler Derneği’nin "Öğretmenlik Meslek Kanunu Hakkındaki Düşünceler" ve CHP’nin 2018 yılı "Öğretmenlik Meslek Kanunu Teklifi" isimli metinler karşılaştırmalı olarak incelenmiştir.

\section{2.ÖĞRETMEN MESLEK KANUNU TASARILARININ İNCELENMESİ}

Türkiye'de öğretmenlerin hakları temel olarak Devlet Memurları Kanunu'nda ve Milli Eğitim Mevzuatında düzenlenmiştir (Karip, 2018: 6). Öğretmenlerin hakları bir tablo halinde gösterilebilir (Levent ve Övür Dönmez, 2019, Tuna, 2021):

\section{Çizelge 1. Öğretmenlerin Haklart}

\begin{tabular}{llll}
\hline Mesleki Hakları & Mali Hakları & Sosyal Hakları & Diğer Hakları \\
\hline Güvenlik ve & Aylık (Maaş) ve & Emeklilik hakkı & Alan Değişikliği \\
Korunma hakkı & Ders Görevi Ücreti & Hastalık ve Analık & Hakkı \\
Başka Görevde & hakkı & Sigortası hakkı & Saygı hakkı \\
Çalıştırılmama & Yolluk hakkı & Aile Yardımı Ödeneği & Şiddet Görmeme \\
İlerleme ve & Eğitim Öğretim & hakkı & hakkı \\
Yükselme hakkı & Tazminatı & Yeniden İşe Alıştırma & Karar Süreçlerine \\
İzin hakkı & Emekli Maaşı ve & hakkı & Katılım hakkı \\
Başvuru, Şikâyet ve & İkramiyesi & Sosyal Tesis & Kendine Adaletli \\
Dava Açma hakkı & Dul ve Yetim & Gereksinimlerinin & Davranılmasını \\
Sendika hakkı & Aylığı hakkı & Karşılanması hakkı & İsteme hakkı, Hesap \\
Çekilme hakkı & Yabancı Dil & Konut Kredisi ve & Verme hakkı \\
Sinıf Değiştirme & Tazminatı & Konut Edinme hakkı & \\
hakkı & & Doğum Yardımı & \\
Yer Değiştirme hakkı & & Ödeneği hakkı & \\
\hline
\end{tabular}




\begin{tabular}{ll}
\hline Ölüm Yardımı Ödeneği \\
hakkı \\
Tedavi Yardımı ve \\
Cenaze Giderlerinin \\
Karşılanması hakkı
\end{tabular}

Çizelge 1'e göre Türkiye'de öğretmenlerin mesleki, mali, sosyal ve diğer hakları bulunmaktadır. Öğretmenlerin meslek kanunu tasarında genel olarak birçok konu üzerinde durulduğu belirtilebilir. Bu belgelerde genel gerekçe, amaç ve kapsam, görevler, sorumluluklar ve haklar, öğretmen yetiştirme ve atama, okul yöneticilerinin görev ve sorumlulukları, okul yöneticilerinin yetiştirilmesi ve ataması, millî eğitim müfettişlerinin seçimi ve ataması, yer değiştirme ve nakil, öğretmenlerin mesleki faaliyetlerinin izlenmesi, değerlendirilmesi ve mesleki gelişimin sağlanması, özlük hakları, mesleki ve etik davranış standartları, disiplin işlemleri ve eğitim öğretim hizmetleri sınıfında fiili olarak görev yapanlara karşı işlenen suçlarda ceza artırımı boyutları üzerinde durulmuştur.

\subsection{Genel Gerekçe}

TEDMEM'in öneri metninde öğretmenliğin profesyonel bir meslek olduğu vurgulanmıştır. Öğretmenlerin Statüsüne İlişkin ILO / UNESCO Tavsiye Kararı ve UNESCO tarafından hazırlanan Herkes İçin Eğitim (EFA) raporlarından kısaca bahsedilmiştir. Bazı meslek kanunları örnek olarak verilmiş, bir milyona yakın personelin olduğu öğretmenliğin meslek kanunun olmamasının bir eksiklik olduğu ifade edilmiştir.

Öğretmenlerin öğretmen yetiştiren programlara sadece çoktan seçmeli bir sınavla alınması, öğretmenlerin çalışma sisteminin ek ders ücreti rejimi gibi bir yöntemle düzenlenmesi, öğretmenliğin devlet memurları kanunu içinde bir memuriyet olarak ele alınması eleştirilmiştir. Dünyada öğretmenlik meslek kanunu olan ülkelerden örnekler verilmiştir.

2018 Cumhurbaşkanlığı ve Milletvekili seçimlerine ilişkin seçim bildirgelerinden yola çıkılarak Mecliste grubu bulunan tüm partilerin “Öğretmenlik Meslek Kanunu” çıkarılması gerektiğine vurgu yaptıkları belirtilmiştir. Ayrıca 23.10.2018 tarihinde kamuoyuna açıklanan MEB 2023 Eğitim Vizyonu belgesinde de "Öğretmenlik Meslek Kanunu” çıkarılması için çalışmalar yapılacağı hatırlatılmıştır.

Öğretmenlikle ilgili yasal metinlere bakıldığında takip edilmesi ve ilişkilendirmesi neredeyse imkânsız hale gelmiş bir mevzuat birikiminin ortaya çıktığı bu yüzden de öğretmenlik mesleğinin hakları, sorumlulukları ve mesleki standartlarının tutarlı ve bütünlük içinde yer aldığı bir çatı ya da üst metne ihtiyaç olduğu belirtilmiştir (TEDMEM, yty, 4). 
Eğitim-Bir-Sen, “Öğretmenlik Meslek Kanunu İhtiyacı” başlığı altında eğitimi açıklarken öğreten-öğrenen ilişkisi üzerinde durmuş; öğretmeni şuur sermayesini artırmaya, bilgi haznesini büyütmeye, idrak zeminini güçlendirmeye, olaya ya da olguya dair hikmeti keşfetmeye dönük eylemleriyle beşerin insanlaşması ve bireyin uzmanlaşması yolculuğunun rehberi olarak kabul ettiklerini söylemiştir (EBS; yty, 3).

Eğitim-Bir-Sen’e göre öğretmeni “öğretmenlik” özelinde değil de kamu personel sistemi içerisinde bir hizmet sınıfı içinde ele alan bir sistem, toplumun meslekten ve meslek mensuplarından beklentilerini karşılamasına imkân verecek esnekliği ve özerkliği sağlayamamaktadır. Öğretmenliğin profesyonel bir meslek olarak değerlendirilmesinin ve mesleki standartlara kavuşmasının yolu bir meslek kanunudur. Bu konuda toplum ve paydaşlar arasında mutabakat söz konusudur (EBS; yty, 3-4).

ÖĞ-DER, kanunun bilimsel çalışmalara dayalı olması, kapsayıcı ve katılımcı olunması, işlevsel ve dengeli olunması, öğretmenlerin hak ve görevlerinin açık bir biçimde tanımlanmasını, kanunun milli köklere dayanmasını, öğretmenleri güçlendirmesini istemektedir (ÖĞ-DER, 2019, 2-5).

CHP, öğretmenlerin hak ettiği toplumsal statü ve saygınlığı sağlayacak, ekonomik ve sosyal hakları düzenleyecek, yetiştirilme ve çalışma şartlarını belirleyecek bir 'Öğretmenlik Meslek Kanunu'na ihtiyaç duyulduğunu belirtmiştir (CHP, 2018, 3).

Sivil Toplum Kuruluşları öğretmenlik mesleğinin önemini vurgulamış, mevcut yasal durumun yetersiz olduğunu, öğretmenliğin profesyonel bir meslek olarak değerlendirilmesi ve mesleki standartlara kavuşabilmesi için meslek kanunun çıkarılması gerektiğini, toplumda bu yönde bir beklenti oluştuğunu ifade etmişlerdir.

\subsection{Amaç ve Kapsam}

TEDMEM'e göre Kanunun amacı; öğretmenlerin görevleri, sorumlulukları, hakları, öğretmen yetiştirme ve istihdamı, öğretmenlerin özlük hakları, okul yöneticilerinin ve millî eğitim müfettişlerinin yetiştirilmesi, istihdamı ve özlük hakları ile ilgili hususların düzenlenmesidir (TEDMEM, yty, 7). 
Eğitim-Bir-Sen, kamu ya da özel öğretim kurumu ayrımı yapılmadan bütün meslek mensuplarını kapsayacak bir öğretmen meslek kanunu hazırlanmasını istemektedir (EBS; yty, $1)$.

ÖĞ-DER, öğretmenlerin haklarını açıkça detaylı biçimde tanımlayan, görev ve sorumlulukları arasında denge kuran, öğretmenlik mesleğini güçlendiren bir kanun amaçlamaktadır.

CHP, bu kanun tasarısının amacının resmi ve özel eğitim kurumlarında görev yapan eğitim çalışanlarının yetiştirilmesi, istihdamı, çalışma usul ve esasları, görev ve yetki, hak ve yükümlülükleri belirlemek olduğu ifade edilmiştir. Kanun, bütün eğitim çalışanlarını kapsamaktadır (CHP, 2018, 5).

\subsection{Görevler, Sorumluluklar ve Haklar}

TEDMEM'e göre öğretmenlerin görev ve sorumlulukları şunlardır: Kendini çocukların, gençlerin ve yetişkinlerin öğrenmesine ve gelişimine adamak; öğrencilerin fiziksel, zihinsel ve ruhsal bütünlügünü korumak; öğrencilerin bireysel özelliklerini dikkate alarak sınıf içi uygulamaları planlamak, yönetmek; öğrencilerin öğrenme süreçlerinde eğitsel rehberlik sağlamak; sınıf içi ölçme değerlendirme çalışmalarını planlamak, yürütmek; her öğrencinin öğrenmesi için çaba sarf etmek; bölgesel ve sınıf içi ihtiyaçları tespit etmek ve bu ihtiyaçları gidermek üzere eylem araştırmaları yapmak; okul içi ve eğitim süreçleriyle ilgili işleyişe dair görüş, fikir ve öneri sunmak; ailelere eğitim öğretim planları, uygulamaları, öğrencinin bireysel ve akademik gelişimi ile ilgili bilgi sağlamak; ders dışı etkinliklerde görev almak; hizmet içi eğitimlere katılmak; mesleki gelişimlerini ve yeterliklerini sürekli geliştirmek.

TEDMEM'in tasarısında öğretmenlerin hakları: Öğretmenlerin okullarda öğretmenlik mesleğinin gereği olarak gerçekleştirdiği her türlü uygulama, iş ve işlemde sadece Kanunda tanımlanmış yetkili kişilere hesap verme hakkı; öğretim yükünün makul ve adil olması hakkı; öğretmenlerin yasal düzenlemelerle kendilerine verilen işlerden başka, meslek dışı, herhangi bir görevle yükümlü tutulmama hakkı; okulda karar alma süreçlerine katılım hakkı; meslek örgütlerine katılma hakkı; saygı görme hakk1; adil değerlendirilme hakk1; kaliteli bir eğitim için gerekli fiziki koşullar, donanım, eğitim araç ve gereçlerine sahip olma hakkı; yapmış olduğu işin güçlük ve yüküne karşılık ücret ve diğer özlük haklarının adil düzenlenmesi hakkı; mesleki gelişim için destek hakkı; kariyer ilerlemelerinde herkese eşit fırsat tanınması hakkı; maaş ve ücretlerini zamanında alma hakkı olarak ifade edilmiştir (TEDMEM, yty, 7-8). 
Eğitim-Bir-Sen, öğretmenin eğitilme iştiyakını artırma ve öğrenme ihtiyacını karşılama sorumluluğunu yüklendiğini aynı zamanda bütün insanlığa uzanan kapsayıcı ve etki üretici sorumluluk alanına da sahip olduğunu ifade etmektedir.

Eğitim-Bir-Sen'e göre öğretmenin görev ve sorumlulukları çok iyi tanımlanmalıdır. Öğretmen eğitim öğretim faaliyetlerinde temel karar alma yetkisine de sahip olmalıdır. Öneri metninden yola çıkarak öğretmenin görev ve sorumluluklarına öğrenci yeterlik ve başarısı, eğitim-öğretim standart ve yeterliklere uygunluk, okul gelişimine katkı örnek olarak verilebilir.

Öğretmenlerin hakları ise, temel haklar ve özlük hakları ekseninde ayrı ayrı ve ayrıntılı olarak belirlenmesi gerektiği ileri sürülmüştür. Metinde "Temel haklar başlığı altında öğretmenlerin öğretme ve öğrenme süreçlerinde, öğrenmeyi ve gelişimi izleme ve değerlendirme alanlarında, program, içerik ve yöntem belirleme aşamalarında, okul-aile-toplum bütününde birey ve kurumlar karşısında, mesleki ilerleme ve gelişim süreçlerinde sahip oldukları haklar ile bunlara paralel yetki, görev ve sorumlulukları ayrıntılı olarak belirlenmelidir" ifadesi kullanılmaktadır (EBS; yty, 8-9).

TEDMEM'e kıyasla Eğitim-Bir-Sen'in öğretmenlerin görev, sorumluluk ve hakları konusunda daha genel ve soyut ifadeler kullandığı söylenebilir.

ÖĞ-DER de öğretmenlerin görev, hak ve sorumluluklarının detaylı biçimde belirlenmesini, öğretmenlerin alanı dışında görevlendirilmemesini ve bütün öğretmelerin kadrolu olmasını istemektedir (ÖĞ-DER, 2019, 4-6).

CHP'ye göre öğretmen görevi dışında başka bir görevde çalıştırılamaz. Öğretmen ders planlarını, yöntemlerini özgürce uygular. Öğretmene saygı duyulur ve baskı yapılamaz. Sendikaya üye olabilir, üye olmaya ya da üyelikten çıkarılmaya zorlanmaz. Kişisel verileri çeşitli ortamlarda kullanılamaz. Eğitim ve öğretimle ilgili her konuda görüş bildirebilir ve görüşleri dikkate alınır (CHP, 2018, 9-10).

\section{4.Öğretmen Yetiştirme ve Atama}

TEDMEM'e göre öğretmen en az lisans düzeyinde ve eğitim fakültelerinde yetişmelidir. Yalnızca öğretmen yetiştirmek üzere açılmış yükseköğretim programı bulunmayan branşlarda öğretmen ihtiyacının karşılanması ile öğretmen yetiştirme lisans programları tarafından karşılanamayan sayıda öğretmen ihtiyacının giderilmesi amacıyla Öğretmenlik Sertifika Programı açılmalıdır. Bu programlar kapsamında yapılan her türlü eğitim öğretim faaliyeti 
bağımsız akreditasyon kuruluşlarınca değerlendirilir. Programda en az bir eğitim öğretim yılı okullarda tam zamanlı uygulama yapılır. Bu süre içinde öğrenci, deneyimli bir öğretmen ile birlikte fiili olarak sınıfa girer. Okullarda öğretmenlik eğitimi uygulamalarının gerçekleştirilmesinde görev alacak öğretmenler için "Uygulama Öğretmenliği Sertifika Programı" düzenlenir.

TEDMEM, öğretmen yetiştiren yükseköğretim programlarına öğrenci seçiminde merkezi olarak uygulanan üniversiteye giriş sınavlarına ek olarak yetenek, yetkinlik, beceri ile insana ve öğrenmeye yönelik tutumlar ile fiziksel ve psikolojik olarak öğretmenlik mesleğine uygunluğun çoklu yöntem ve araçlarla değerlendirilmesine dayalı bir seçme ve yerleştirme önermektedir.

Eğitim-Bir-Sen, öğretmen adaylarının/aday öğretmenlerin, öğretmenlik alan bilgisinin yanı sıra, uygulama temelli tasarlanmış öğretmen eğitimine tabi olmaları gerektiğini düşünmektedir. Öğretmen adaylarının yetiştirilmesiyle ilgili her program; genel kültür, temel mesleki öğrenim, öğretmen adayının öğretimini yerine getirmek istediği alana ilişkin öğrenim ve danışman öğretmenlerin yönetimi altında okulda öğretim ve yükseköğretim kurumu dışında etkinlikler bölümlerini içermelidir.

TEDMEM, öğretmenlerin daimi kadrolu olarak atanmasını istemektedir. Öğretmenler, yalnızca geçici, belirli süreli ve acil ihtiyaçların karşılanması için vekil öğretmen ve ücretli öğretmen çalıştırılması dışında farklı statülerde çalıştırılamaz. Her eğitim öğretim yılı sonunda öğretmenlikte boş kadro sayısı Millî Eğitim Bakanlığı tarafından belirlenerek, öğretmen ihtiyacı kadar öğretmenlik kadrosu ihdas edilir ve eğitim öğretim yılı başlamadan önce öğretmen atamaları yapılır (TEDMEM, yty, 9-15).

Eğitim-Bir-Sen, mesleki sürekliliği ve istihdamı/iş güvencesini, kamu hizmeti vasfı tartışılmaz olan eğitim-öğretim hizmetinin niteliğinin artırılması ve korunması için kaçınılmaz olarak görmektedir. Bu nedenle, mesleki sürekliliği sağlayacak bir iş güvencesi, eğitim sisteminin bütünü veya bir kısmının örgütlenişinde değişiklikler yapıldığı zaman bile güvence altına alınmalıdır. Öğretmenler, iş güvencelerini, mesleki özerkliklerini, mesleki durumlarını ya da kariyerlerini etkileyecek nitelikteki keyfî eylemlere karşı etkili bir biçimde korunmalıdır. Eğitim-öğretim hizmetlerinin tam zamanlı çalışan öğretmenler eliyle yürütülmesi kural olmalı; kısmi zamanlı çalışma ancak hizmetinin niteliğinin zorunlu kıldığı durumlarda mümkün olabilmelidir (EBS; yty, 5-7). 
TEDMEM'e göre öğretmen adayları atamaya esas puanlarının hesaplanmasına kısmi olarak esas teşkil edecek Öğretmenlik Yeterlik Sınavına girmelidir. Adaylar Bakanlık tarafından duyurusu yapılan il bazında boş kadrolar için il tercihlerini ve il tercihlerinin sıralamalarını, en fazla beş (5) il ile sınırlı olmak üzere elektronik ortamda yapar. Başvuru sürecinin sonuna kadar, adayların tercih yaptıkları il için başvuru yaptıkları alan veya branş bazında başvuru yapan aday sayısı ve başvuru yapan adayların merkezi sınavdan aldıkları puanların dağılımını görmeleri sağlanır. Her bir ilde alan veya branş bazında boş norm kadro sayısının üç katı kadar aday sözlü değerlendirmeye alınır. Birden fazla ilde sözlü değerlendirmeye alınacak adayların sözlü değerlendirme günleri en az 24 saat aralıklı olacak şekilde elektronik ortamda belirlenir. İl düzeyinde Sözlü Değerlendirme Komisyonu kurulur. Sözlü değerlendirmede alanın veya branşın eğitim öğretimine ve öğretmenlik mesleğine yönelik tutumların değerlendirilmesine yönelik sorular üzerinden değerlendirme yapılır. Sözlü değerlendirmede adayın salona girişinden çıkışına kadar olan süreç görüntülü ve sesli olarak kayıt altına alınır. Adayların öğretmenliğe atamaya esas teşkil edecek puanının \%75'ini Öğretmenlik Yeterlik Sınavından aldıkları puan, \%25'ini ise sözlü değerlendirmeden aldıkları puan oluşturur (TEDMEM, yty, 9$15)$.

Eğitim-Bir-Sen’e göre resmi veya özel öğretim kurumu ayrımı yapılmaksızın öğretmen adaylarının meslek adaylığına kabulleri, mesleki bilgiyi ölçmeye yönelik bir yeterlik sınavıyla gerçekleştirilmeli; resmî öğretim kurumları yönünden KPSS asgari puanı ön şart olarak aranmalidir (EBS; yty, 5).

TEDMEM, öğretmenlerin mesleğin ilk yılında yoğun ve odaklı destek alacakları mesleki uyum sürecine dâhil olmalarını istemektedir. Bu kapsamda, yeni atanan öğretmenlere doğrudan sınıf içi eğitim uygulamalarına ve öğrenme-öğretme süreçlerine odaklanan mesleki gelişim desteği sağlanır. Mesleki uyum sürecinde öğretmenlerin izleme ve değerlendirilmesi kendi branşından bir danışman öğretmen ile okul yöneticisi tarafından gerçekleştirilir. Mesleki uyum sürecinin sonlandırılması ile ilgili iş ve işlemler; danışman öğretmen ve okul yöneticisinin yapacağı ortak değerlendirme ile gerçekleştirilir. Gerekli değerlendirmeler sonucunda bu süreç en fazla üç yıla kadar uzat1labilir (TEDMEM, yty, 9-15).

Eğitim-Bir-Sen, öğretmenlik mesleğine girişte staj uygulamasını savunmaktadır. Adaylıktan asli öğretmenliğe geçiş sürecindeki başarı şartları mesleki nitelikte olmalı; staj süresi içinde başarısız bulunan öğretmen adayı, kendisine yöneltilen yetersizlikler ve başarısızlık sebepleri konusunda bilgilendirilmeli ve bunlara karşı itiraz hakkı olmalı; 
öğretmenlerin çoğunluğu teşkil edeceği bir kurul nezdinde itirazlar yargısal denetime elverişli olacak şekilde değerlendirilebilmelidir.

Eğitim-Bir-Sen'e göre stajyerlik döneminin mesleki gelişim etkinliklerinin içerik ve yöntemi, öğretmen yeterliklerinin geliştirilmesini sağlayacak bir niteliğe kavuşturulmalıdır. Stajyer öğretmenlerin, stajyerlik yılını öğretmen kadrosu ve imkânları daha fazla olan belirlenmiş bir okulda ve deneyimli bir danışman öğretmenin rehberliğinde tamamlamaları sağlanmalıdır (EBS; yty, 5-7).

ÖĞ-DER'e göre; mesleğe kaynaklık edecek yükseköğretim kurulları sadece Eğitim

Fakülteleri ile sınırlı olmamalıdır. Bu fakültelerde uygulamaya daha çok ağırlık verilmelidir. Mesleğe seçim merkezi sınavla olmalı, sınav içeriği; alan bilgisi ve meslek bilgisi olmalıdır. Sözlü sınav mülakat olmamalıdır. Aday öğretmenlik olmalı, iki yıl başarısız olanlar devlet memurluğundan alınmamalı başka bir uygun göreve atanmalıdır (ÖĞ-DER, 2019, 5-7).

CHP, öğretmenlik mesleğine girişte dört yıllık fakülte mezunu olmayı önkoşul kabul etmektedir. Öğretmen Yetiştirme ve İstihdam Kurulu, öğretmen yetiştirme ve istihdamı amacıyla kurulacaktır. Öğretmen yetiştirme süreci hizmet öncesi ve hizmet içi olmak üzere iki bölümden oluşur. Hizmet öncesi eğitim fakültelerinde, hizmet içi eğitim Türkiye Eğitim Bilimleri Akademisi tarafından yapılır. Aday öğretmen kendi branşında deneyim sahibi bir öğretmen rehberliğinde çalışır. Bir yılın sonunda Türkiye Eğitim Bilimleri Akademisi tarafından yapılacak yazılı sınava girer. Sınavda başarılı olanlar öğretmen olmaya hak kazanır. Öğretmenlerin atanmasında mesleki yeterlilik ve liyakat esas alınır (CHP, 2018, 6-8).

\subsection{Yer Değiştirme ve Nakil}

TEDMEM'e göre öğretmenler mesleğe ilk atamada atandığı okulda en az dört yıl süreyle fiili olarak görev yapmalıdır. Öğretmenlerin yer değiştirme ve nakil işlemleri, yer değiştirme veya nakil istedikleri yerlerde boş kadro bulunması halinde öğretmen atama dönemi öncesinde ve okulların eğitim öğretime ara verdiği yaz dönemi içinde sağlık ve can güvenliği durumları hariç norm kadro esasına göre yapılmalıdır. Norm fazlası durumuna düşenlerin, eğitim öğretim hizmetleri ile ilgili ders, kurs, telafi programları ve her türlü eğitim öğretim faaliyetlerinde görevlendirilerek iş yüklerinin tamamlanması sağlanmalıdır (TEDMEM, yty, 19).

Eğitim-Bir-Sen'e göre atama ve yer değiștirmelerde öğretmenlerin tercih ve istekleri esas alınmalı; aile bütünlüğü, sağlık mazereti, üst öğrenim hakkı, can güvenliği gibi yer değişikliği 
talep etme hakkı doğuran mazeret sebeplerinin değerlendirilmesi anayasal haklar çerçevesinde düzenlenmelidir. Atama ve yer değiştirmeler hizmet puanı üstünlüğüne göre yapılmalıdır. Hizmet puanının belirlenmesi yöntemi ise sadece coğrafi yer esasına göre değil bireysel üstün çaba ve fedakârlığg gözeten ve teşvik eden çoklu değerlendirme kriterlerine göre tasarlanmalıdır (EBS; yty, 12).

Türkiye'de yakın zamana kadar öğretmenlerin atama ve yer değiştirmeleri eğitim öğretiminin aksamasına yol açabiliyordu. TEDMEM'in önerilerinde atama ve yer değiştirmelerin eğitim öğretimi aksatmadan yapılması esas tutulmuştur. Eğitim-Bir-Sen ise öğretmen merkezli önerilerde bulunmuştur. Hizmet puanını hesaplama şeklinin çeşitlendirilmesi öğretmenleri motive edebilir yorumu yapılabilir. Öğretmenlerin yer değiştirme hakkı vardır, bu konuda belirli esaslar göz önünde bulundurulur ve bu konu yönetmelikle belirlenir.

CHP kanun teklifinde atama ve yer değiştirme için Bakanlığın kılavuzunu en az iki ay önce açıklayacağını ifade eder. Bakanlık başvurunun belirli yerler için yapılmasını isteyebilir. Bakanlık belirli koşulları taşıyanlara zorunlu hizmet koyabilir. Norm kadro esaslarına uyulur (CHP, 2018, 14-15).

\subsection{Okul Yöneticilerinin Görev ve Sorumlulukları}

TEDMEM, okul yöneticilerinin görev ve sorumluluklarını Milli eğitimin temel amaçlarıyla okulun genel amaçlarına ulaşabilmek için öğretim ve yönetim süreçlerinin planlanması, izlenmesi ve değerlendirilmesi olarak özetlemiştir.

Okul müdürü atamaları kadro karşıllğı yapılır. Okul müdürlüğü için Okul Yöneticisi Yetiştirme Programını başarıyla tamamlamak şartı dikkat çekmektedir (TEDMEM, yty,16).

Eğitim-Bir-Sen de eğitim kurumu yöneticiliğinin kadro unvanına sahip olması gerektiğini ifade etmektedir. Ayrıca eğitim kurumu yöneticiliği kariyer mesleği haline getirilmelidir (EBS; yty, 16).

\subsection{Okul Yöneticilerinin Yetiştirilmesi ve Ataması}

TEDMEM'e göre okul müdürü atamaları kadro karşılığı yapılır. Belirli bir kuruma öğretmen olarak atanabilme yeterliğine sahip olanlar o kuruma okul müdürü olarak atanabilir. Okul müdürlüğü için ilgili kademede veya okul türünde en az 5 yıl öğretmenlik yapmış olmak, en az 
2 yıl müdür yardımcılığg yapmış olmak, devlet memuru olmak için aranan genel şartları taşıyor olmak ve Okul Yöneticisi Yetiştirme Programını başarıyla tamamlamak şartları aranır.

Okul müdür yardımcılığı için ilgili kademede en az 3 yıl öğretmenlik yapmış olmak, devlet memuru olmak için aranan genel şartları taşıyor olmak ve Okul Yöneticisi Yetiştirme Programını tamamlamak şartları aranır.

Okul müdürü yeter sayıda adayı ilçe Millî Eğitim Müdürlüğüne sunar. Okul içinde okul müdür yardımcısı olma niteliğini taşıyan aday olmaması durumunda, İlçe Milli Eğitim Müdürlüğünce ilana çıkılır. İlçe genelinde diğer okullarda görev yapan ve okul müdür yardımcısı olma niteliğini taşıyan öğretmenlerden başvuru alınır.

Müdür yardımcılarının görev süresi, her ne sebeple olursa olsun okul müdürünün görev süresinin sona ermesi veya görevden ayrılması halinde yeni Müdürün atanmasını izleyen bir ay içinde kendiliğinden sona erer (TEDMEM, yty, 16-17).

Eğitim-Bir-Sen'e göre eğitim kurumu yöneticiliğine atama, Bakanlıkça yürütülecek eğitim kurumu yöneticiliği/eğitim yönetimi alanında belli bir süreye dayalı sertifikasyon programını ve ardından gelecek yazılı yeterlik sınavını tamamlamış ya da bu alanlarda lisansüstü eğitim yapmış öğretmenler arasından Bakanlıkça yapılacak bir yazılı sınav sonucuna göre gerçekleştirilmelidir (EBS; yty, 15).

ÖĞ-DER'e göre; okul yöneticiliği yapacak öğretmenler hakkında detaylı ve net kıstaslar belirlenmelidir. Buna göre tecrübe en az 5 yıllık ve okul türüne uygun olmalı, müdür yardımcılığında da en az 3 yıllık tecrübe olmalı. Merkezi sınav olmalı, yönetici eğitim programları zorunlu kılınmalıdır (ÖĞ-DER, 2019, 7).

CHP yasa tasarısında kadın eğitim yöneticilerine pozitif ayırımcılık yapılmasını önerir. Buna göre ülke genelinde dağılım oranı, 1/2 cinsiyet kotası olarak uygulanacaktır. Eğitim yöneticileri Milli Eğitim Akademisi programlarında yetiştirilen personel arasından seçilecektir. İstekli, başarılı öğretmenler bu programlara yönlendirilecektir (CHP, 2018, 11-12).

\subsection{Millî Eğitim Müfettişlerinin Seçimi ve Ataması}

TEDMEM'e göre Millî Eğitim Müfettişleri ve Millî Eğitim Müfettiş Yardımcılarının atamaları kadro karşılı̆̆ında yapılmalı. Millî Eğitim Müfettişleri eğitim öğretim hizmetlerinin yürütülmesi ile mali ve idari konularda denetim, inceleme, araştırma, soruşturma ve rehberlik 
faaliyetlerini yürütmekten sorumludur. Okul müdürü olarak atanabilme yeterliğine sahip olanlar Millî Eğitim Müfettişi ve Millî Eğitim Müfettiş Yardımcısı olarak atanabilir (TEDMEM, yty, 18).

Eğitim-Bir-Sen'in önerileri arasında müfettişlikle ilgili bir düzenlemeden bahsedilmemiştir.

ÖĞ-DER müfettiş alımlarında okul müdürlüğü, uzmanlık gibi tecrübeye öncelik tanınmalı ve sınav merkezi olmalı görüşündedir (ÖĞ-DER, 2019, 7).

CHP yasa teklifinde eğitim müfettişlerinin eğitim yöneticileri gibi Milli Eğitim Akademisi mezunlarından sınavla seçileceğini belirtir. Amaç eğitim personeli ve hizmetinin geliştirilmesi ve eğitimde verimin artmasına yardımcı olmaktır (CHP, 2018, 16).

\section{9.Öğretmenlerin Mesleki Faaliyetlerinin İzlenmesi, Değerlendirilmesi ve Mesleki Gelişimin Sağlanması}

TEDMEM, öğretmenlerin ve okul yöneticilerinin sürekli mesleki gelişiminin sağlanması ve mesleki gelişim haklarının güvence altına alınmasını esas olarak görmektedir. Mesleki gelişim etkinlikleri okulda eğitim öğretim devam ederken veya eğitim öğretime ara verildiği dönemlerde yapılır. Bu eğitimlerin maliyeti öğretmenin kurumu tarafından karşılanır. Faaliyetler ve sonuçlarına ait bilgiler dijital ortama kaydedilir. Öğretmenlerin mesleki gelişimini destekleyecek çalışmalar; birincisi okul temelli mesleki gelişim çalışmaları, ikincisi lisansüstü düzeyde öğretmen yetiştiren eğitim kurumları tarafından sunulan mesleki gelişim faaliyetleri olmak üzere iki boyutlu olarak gerçekleştirilir (TEDMEM, yty, 19-22).

Eğitim-Bir-Sen'e göre, mesleki gelişim, öğretmenler açısından bir haktır. Mesleki gelişimin temelinde, mesleğe yeni başlayan öğretmenler için danışmanlık programları ile öğretmenlerin mesleki gelişimlerini destekleyecek etkinliklere katılımlarının sağlanması ve teşvik edilmesi, öğretmenler arası iş birliği ve birlikte çalışma kültürünün pekiştirilmesi hedeflenmelidir. Mesleki gelişim programları, öğretmenlerin seçimine sunulacak şekilde çeşitliliğe sahip olmalıdır. Mesleki gelişim programlarının hazırlanmasında genel yeterliklerin başat referans olacağı hususu gözetilmelidir. Bu programların oluşturulması ve geliştirilmesi süreçleri ile bu programları uygulayacak kurumların yönetiminde öğretmenlerin, sendikaların ve eğitim fakültelerinin yer alması sağlanmalıdır (EBS; yty, 16). 
Öğretmenlerin çalışma şartları, öğretmenlere mesleki çalışmalara daha fazla zaman ayırma imkânı verecek şekilde tasarlanmalıdır. Öğretmenlerin kendilerine uygun mesleki gelişim programlarına erişim hakkı tanınmalı; mesleki gelişim ve yetkinliklerinin artırılmasına yönelik programlardan ücretsiz faydalanmaları veya idari-mali açıdan desteklenmeleri gerektiği esas kabul edilmelidir.

TEDMEM'e göre okul müdürü, öğretmenlerin her türlü mesleki faaliyetleri ile sınıf içi eğitim öğretim uygulamalarını izlemek, değerlendirmek ve geliştirmek için gerekli tedbirleri almalıdır. $\mathrm{Bu}$ sürece millî eğitim müfettişleri, başöğretmenler, müdür yardımcıları ile zümre başkanları katkı sağlarlar.

İzleme, değerlendirme ve geliştirme sürecinde öğretmenlerin öz değerlendirme yapmaları ve sürece etkin katılımları temin edilir, eğitim öğretim faaliyetlerine odaklanılır. Somut bilgi, belge ve gözlemlere dayalı olarak oluşturulan verilerden ve bulgulardan yola çıkarak yapılan değerlendirmeden elde edilen sonuçlar öğretmen ile müzakere edilerek öğretmenin gelişim ihtiyaçları ve hedefleri belirlenir. Her öğretmen için Bireysel Gelişim Planı oluşturulur ve bir önceki yılla bağlantılı biçimde periyodik olarak takip edilir.

İzleme ve değerlendirme faaliyetleri sonucunda okul yönetimi tarafindan alınan tedbirlere rağmen iki yıl üst üste gelişme göstermeyen, gerekli desteğin sağlanmasına karşın mesleki gelişim etkinliklerine katılmayan veya gerekli çalışmaları yapmayan öğretmenler okul müdürü, ilgili müdür yardımcısı, zümre başkanı ile bir millî eğitim müfettişinden oluşan komisyon tarafından yapılacak ortak değerlendirme doğrultusunda bir yıllık süre için izlemeye alınır; gerekli uyarılar ve öneriler yazılı olarak bildirilir. Üçüncü yılın sonunda söz konusu komisyon nihai değerlendirmeyi yaparak, öğretmenin gerekli gelişmeyi gösteremediği, uyarıların ve önerilerin gereği olan çalışmaları yapmadığı açık bir şekilde kanıtlanması ile bu durumun öğrencilerin eşit ve adil bir eğitim alma haklarının ihlali sonucunu doğurduğunun tespiti halinde, öğretmenin öğretmenlik mesleğine devam etmemesi yönünde oluşturacağı tavsiye kararını İl Millî Eğitim Müdürlüğüne bildirir. Öğretmenin öğretmenlik mesleğine devam etmemesi yönünde oluşturacağı tavsiye kararının İl Millı̂ Eğitim Müdürlüğüne bildirilmesini takip eden 15 gün içinde İl Millî Eğitim Müdürlüğü gerekli iş ve işlemleri tamamlayarak tavsiye kararını İl Milli Eğitim Müdürlüğünün görüşü ile birlikte Milli Eğitim Bakanlığına gönderir. Bakanlık söz konusu öğretmen ile ilgili nihai kararı İl Milli Eğitim Müdürlüğünün görüşünün ve ilgili belgelerin Bakanlığa ulaştığı tarihten itibaren 60 gün içinde sonlandırır (TEDMEM, yty, 19-22). 
Eğitim-Bir-Sen'e göre, eğitim-öğretim süreçlerinde mesleki yeterlik ve beceriyi öne çıkarmaya odaklı bir rehberlik sisteminin ana unsurları tanımlanmalı. Meslek pratiklerinin denetiminin ve teftiş süreçlerinin kimler tarafından nasıl yürütüleceği ve hangi somut sonuçlara bağlanacağı belirlenmelidir (EBS; yty, 17-18)

Öğretmenin okulun öğrenme ortamına dâhil olarak diğer öğretmenlerin gelişimlerine katk1 sağlamasını, meslektaşlarına geri bildirimlerde bulunmasını, mesleğe başlayan öğretmenlerin uyum süreçlerini desteklemesini ve okulda danışmanlık uygulamalarına katkı sağlamasını esas ilkeler olarak belirleyen bir özdenetim sistemi inşa edilmelidir. Türkiye’de öğretmenlerin değerlendirilmesi için, hâlihazırda kullanılan dış teftiş mekanizmaları yerine meslektaşlar olarak öğretmenlerin kendi kendilerini değerlendirmeleri (akran değerlendirmesi) sağlanmalıdır

Her teftiş ve denetim sistemi, mesleki görevlerinin yerine getirilmesinde öğretmenleri özendirici ve destekleyici, öğretmenlere yardım edici/yol gösterici biçimde tasarlanmalı ve öğretmenlerin özgürlüğünü, girişkenliğini ve sorumluluğunu sınırlamaktan kaçınmalıdır.

Öğretmenin etkinliğinin ve çalışmasının, takdir hakkı içeren mahiyette doğrudan bir değerlendirme ve inceleme konusu edildiği hâllerde, bu değerlendirme önceden belirlenmiş nesnel ölçütlere göre yapılmalı ve öğretmenin bilgisine sunulmalıdır. Öğretmenin kendisi hakkında yapılan değerlendirmenin haksız olduğunu düşündüğü hâllerde değerlendirmeye karşı itiraz/başvuru hakkı olmalı; bu itirazın değerlendirmesi öğretmenlerin çoğunluğu oluşturduğu kurullarca yapilmalıdır.

Meslekten çıkarılma şartları süreci mesleki yetersizlikten kaynaklı hâller ve disiplin fiillerinden kaynaklı hâller gibi farklı çıkarılma sebepleri ekseninde ayrı ayrı ele alınmalı; öğretmenlere bu süreçte kendilerini savunma ve istemin aksini ispatlama hakları tanımlanmalı; bu hususta verilecek kararlara karşı dava açma yoluna gidilmesinden evvel yargı organları önünde delil niteliğinde olacak şekilde itiraz/ön başvuru hakkı tanınmalı; meslekten çıkarılma süreçlerinde sadece istihdam edenlerin değil, üye olunan sendikanın ve meslektaşların da karar verme ve oy hakkı bulunmalıdır.

TEDMEM, uzman öğretmenlik için mesleki uyum süreci sonrası en az beş yıl fiili olarak öğretmenlik yapmış olmak ve kendi alanında veya branşında yüksek lisans derecesine sahip olmak şartı arar. Bu şartlara ek olarak uzman öğretmenlik, eğitim öğretim uygulamalarında çalışmalarını ve başarılarını gösteren, dezavantajlı, öğrenme eksiği olan öğrencilere öğrenme 
desteklerini ve öğrencilerin gelişimine ilişkin kanıtları içeren planlar ile eğitim öğretim uygulamalarına ve uygulamaların çıktılarına ilişkin değerlendirme sonuçlarına dayalı olarak elde edilen bir unvandır. Uzman öğretmen sayısı ildeki toplam öğretmen sayısının \%15'ini geçemez. Başöğretmenlik için mesleki uyum süreci sonrası en az 10 yıl fiili olarak öğretmenlik yapmış olmak, uzman öğretmenlik için tanımlanan diğer koşulları tamamlamış olmak ve kendi alanında veya branşında doktora derecesine sahip olmak şartları aranır. Baş̧öğretmen sayısı ildeki toplam öğretmen sayısının \%5'ini geçemez (TEDMEM, yty, 19-22).

Eğitim-Bir-Sen, öğretmen kariyer basamaklarını, aday öğretmen, öğretmen, uzman öğretmen ve başöğretmen şeklinde belirtmektedir. Öğretmenlerin, gerekli nitelikleri ve yeterlikleri taşımaları şartıyla, kariyer basamakları boyunca ilerlemeleri temel bir hak olarak tanımlanmalı; bu hak herhangi bir kontenjan şartına veya snnılamaya tabi tutulmamalıdır. Kariyer basamaklarında yükselmeler, belirlenmiş mesleki nitelikli ölçütlere göre, öngörülen basamak için öğretmenin niteliklerinin nesnel bir değerlendirmesi temeline dayanmalıdır (EBS; yty, 10).

ÖĞ-DER'e göre; performans sistemi kurgulanmalı ancak branş farklı1ıkları gözetilmelidir (ÖĞDER, 2019, 12). Öğretmenlik mesleki gelişimi için Bakanlıkça Sürekli Eğitim Merkezi, Öğretmen Akademisi gibi eğitim birimleri kurulması yer almalıdır (ÖĞ-DER, 2019, 8).

CHP yasa teklifinde öğretmenlere Milli Eğitim Akademisi tarafından hizmet içi eğitim verilir. Akademi, üniversitelerle işbirliği yapar. Eğitim Fakülteleri işbirliğiyle Türkiye Eğitim Bilimleri Akademisi kurulur ve hizmet içi eğitim programları düzenlenir (CHP, 2018, 16-17).

\subsection{0.Özlük Hakları}

TEDMEM'e göre öğretmen ve yöneticilere devlet memurları kanununda belirtilen en yüksek devlet memuru aylığının (ek gösterge dahil) brüt tutarının;

a) Okul/kurum müdürleri için $\% 350$ si,

b) Müdür yardımcıları için \%275 i,

c) Başöğretmenler için $\% 300$ ü,

ç) Uzman öğretmenler için \%215 i,

d) Öğretmenlerden 1-2 nci derecelerden aylık alanlar için \% $210 \mathrm{u}$,

e) Öğretmenlerden 3 ve 4 üncü derecelerden aylık alanlar için \% 200 ü, 
f) Öğretmenlerden 5, 6, 7, 8, ve 9 uncu derecelerden aylık alanlar için \% 195 i, kadar eğitim öğretim tazminatı ödenmelidir.

Eğitim öğretim tazminatları okulların öğrenci sayıları ve dezavantajlı okul veya daha az tercih edilen okul olma özellikleri dikkate alınarak artırılabilir.

Öğretmenlerin haftalık iş yükleri 35 saat olarak düzenlenmelidir. Özel öğretim kurumlarında haftalık çalışma İş Kanununda tanımlanan çalışma süresidir.

Her eğitim öğretim yılı başında öğretmenlik yapanlara eğitim öğretim yılı hazırlık ödeneği ödenir.

Konut kiralama ve yaşanabilir bir konut bulma imkânı olmayan yerleşim birimlerinde öğretmenler için konut temini Bakanlıkça sağlanır.

Dezavantajlı yerleşim birimlerinde eğitim öğretim sınıfında görev yapanlar için söz konusu bölgede görev yaptıkları her bir yıl için 60 gün yıpranma payı hakkı verilir.

Öğretmenler eğitim öğretim faaliyetlerine ara verildiği dönemde yıllık izinlerini kullanmış say1lirlar.

Öğretmenlerin emeklilik işlemleri eğitim öğretim yılının son iş gününü izleyen 30 gün içinde yapılır. Emeklilik hakkını kullanmak isteyen öğretmenler emekli olacaklarını ikinci yarıyılın başlangıcından itibaren 6 hafta içinde bildirmekle yükümlüdür (TEDMEM, yty, 23-25).

Eğitim-Bir-Sen'e göre resmî eğitim kurumlarında görev alan öğretmenlerin mali ve sosyal hakları, öğretmenlik mesleği ve kıdemleri özelinde geliştirilerek tek tek sayılmalı; özel öğretim kurumlarında görev alan öğretmenlerin ise kıdemlerine göre dengi resmî öğretim kurumlarında ödenen aylık ile sosyal yardım kapsamındaki tutarlarından az ücret verilemeyeceği şeklinde düzenleme yapılmalıdır (EBS; yty, 11-12).

Maaş, ücret ve gelir farklılıkları; kariyer basamakları, belgelendirilmiş mesleki gelişim, kıdem ya da sorumluluk derecesi gibi nesnel ölçütlere dayanmalıdır.

Öğretmenin günde ve haftada ilgilenmek zorunda olduğu öğrenci sayısı, derslere hazırlık için gerekli zaman, her gün verilecek değişik derslerin sayısı ve süresi, öğretmenlerin araştırmalara, okul dışı etkinliklere katılmaları, öğrencileri denetlemeleri için gerekli görülen zaman gibi unsurlar belli bir asgari standarda bağlanmalı ve ilave mali haklar ve ücretle ilişkilendirilmelidir. 
Öğretmenlerin özlük hakları, mali hakları, aylıkları, ücretleri, sosyal hakları ve çalışma koşulları, sendikalar ile işverenler arasında toplu görüşmeler/toplu sözleşme yoluyla belirlenmelidir.

Öğretmenlerin ücretleri, öğretmenlik işlevinin ve bu işlevin toplum için taşıdı̆̆ önem kadar, mesleğe girişlerinden başlayarak öğretmene düşen her tür sorumluluğa yakışır olmalıdır.

Türkiye'de öğretmen maaşları OECD verileri esas alınarak iyileştirilmeli ve tecrübenin maaşa etkisi yeniden düzenlenmelidir. Bu çerçevede, doğrudan öğretmen maaşlarını iyileştirmeye yönelik adımlar, hayat pahalılığından kaynaklanan artışa mukabil öğretmen maaşlarında düzeltme ve genel olarak kamu sektöründe maaşların düzeltilmesi temel alınarak bir iyileştirme mekanizması kurulmalıdır.

Öğretmenlerin bölgeler arası ve kent-kırsal arasındaki dengesiz dağılımını gidermeye yönelik düzenlemeler yapılmalı, öğretmenlerin kalkınmada öncelikli yörelerde ve kronik istihdam açığı bulunan bölgelerde görev yapmaları ve orada uzun süre kalmaları özendirilmelidir.

Öğretmenlerin maaşlarında, hizmet ettikleri bölgelerin zorluk derecesine göre ilave ödeme yapılmasını sağlayacak kalemlere yer verilmelidir.

CHP'nin yasa teklifine göre; öğretmenin özlük dosyası vardır ve bu dosya öğretmenin görev yaptığı ilçede saklanır. Öğretmenlerin ekonomik hakları teminat altına alınır. Öğretmenlerin göreve başladığ 1 ilk maaşları en yüksek devlet memurunun maaşının bürüt \%50'sinden aşağı olamaz. 5 Ekim Dünya Öğretmenler Günü ve 24 Kasım Öğretmenler Günü bir maaş ikramiye verilir. Eğitim öğretim dönemi başında bir maaş tutarı hazırlık ödeneği verilir. Aylık karşılı̆̆ı ders görevi branş öğretmenleriyle sınıf öğretmenleri eşit olacaktır. Öğretmenler sosyal haklardan yararlanacaktır. Tüm öğretmenlerin sağlık, sosyal ve yardım ve dayanışmalarını sağlayacak Öğretmen Sosyal Yardımlaşma ve Dayanışma Kurumu kurulacaktır (CHP; 2018, 10-17).

\subsection{Mesleki ve Etik Davranış Standartları}

TEDMEM, öğretmenlerin öğretmenlik meslek etiği davranış ilkelerine uymayı taahhüt eden bir sözleşme imzalamasını önermiştir. Öğretmenlerin mesleğine, öğrencilerine, meslektaşlarına, velilerine karşı uyması gereken etik davranışlar ile yöneticilerin uyması gereken etik davranışlar maddeler halinde sayılmıştır. Mesleğe ilişin etik davranışlar ile 
öğrencilere gösterilmesi istenen etik davranışlar örnek olarak alınmıştır (TEDMEM, yty, 2628):

\section{Öğretmenlik Mesleğine İlişkin Etik Davranışlar}

a) Görevinin gerektirdiği bilgi, nitelik ve yeteneklere sahip olabilmek için, her türlü bilgiyi, bilimsel ve teknolojik gelişmeleri takip ederek gelişimini sürdürür.

b) Mesleğini sevmediği izlenimini gösterecek davranışlardan kaçınır.

c) Eğitim ve öğretimin güven ve düzen içinde yapılmasını sağlar.

ç) Çalıştığı kurum veya kuruluşun amaçlarına ve misyonuna uygun davranır.

d) Derse geç girerek, dersten erken ayrılarak ya da gerçeğe aykırı mazeretler üreterek eğitim sürecini kesintiye uğratmaz

e) Ders saatlerini etkin ve verimli kullanır.

f) Dersten geç ayrılmak suretiyle öğrencinin dinlenme hakkını engellemez.

g) Öğretmenler Günü gibi özel gün ve haftalarda verilen, maddi değeri olmayan sembolik nitelikteki hediyeler hariç, mesleki kararını ve tarafsızlığını etkilemesi muhtemel herhangi bir hediyeyi kabul etmez.

h) Mesleki nüfuzunu kullanarak kişisel menfaat sağlamaz; kurum kaynaklarını, araç ve gereçlerini kişisel amaç için kullanmaz.

1) Kendi öğrencilerine ücret veya başka bir menfaat karşılığı özel ders vermez.

i) Öğrenci ve velilerden bağış, yardım veya başka bir isim altında para ya da eşya talebinde bulunmaz, bunlarla ilgili zorunluluk getirmez.

\section{Öğretmenlerin Öğrencilere Karşı Etik Davranışları}

a) Dil, ırk, renk cinsiyet, siyasi düşünce, felsefi inanç, din, mezhep ve benzeri farklılıklara göre ayrım yapmaksızın gözetmeden, öğrencilere adil ve eşit davranır.

b) Öğrencilerin farklılıklarını gözetmeksizin anlayış ve hoşgörü ile yaklaşır. 
c) Öğrenciyi utandıracak, onurunu kıracak söz ve davranışlardan hassasiyetle kaçınır.

ç) Söz, davranış, hal, hareket ve görüntüsü ile öğrencilere iyi örnek olur, kötü örnek oluşturacak tutum ve davranışlardan kaçınır.

d) Öğrencinin özel hayatına yönelik bilgileri korur, yasal ve mesleki gereklilikler nedeniyle zorunluluk olmadıkça kimseyle paylaşmaz.

e) Öğrencilerin fiziksel, duygusal, sosyal, kültürel ve ahlaki gelişimlerini gözetir, bu doğrultuda öğrencileri ile güvene dayalı iletişim kurar.

f) Bedenen ve ruhen sağlıklı, iyi ahlaklı, kendine güvenen, sorumluluk sahibi bireyler yetiştirmek için gereken çabayı gösterir.

g) Kişisel, ailevi ve çevresel nedenlerle üzüntü, sıkıntı, mutsuzluk gibi kişisel durumlarını öğrencilere yansıtmaz ve onları açıklamaz.

h) Öğrencinin beden ve ruh sağlı̆̆ını, fiziksel, sosyal gelişimini ve eğitimini olumsuz yönde etkileyecek şekilde davranmaz.

1) Bir öğrencinin okul içinde ve okul dışında kötü muameleye uğradığını fark ettiğinde gerekli tedbirleri alır, durumu yetkili makamlara bildirir.

Eğitim-Bir-Sen'in metninde etik kurallar, öğretmenleri cezalandırma amacı gütmeksizin kabul edilen ilkelere göre, mesleğin saygınlığını ve mesleki ödevlerin yerine getirilmesini sağlama amacı gütmeli ifadesi geçmektedir (EBS; yty, 16-17).

ÖĞ-DER bu konuda genel bir öneride bulunur: Mesleki etik davranışlar belirlenmeli, bu davranış ve ilkeler; kapsayıcı, özgürlükçü, demokratik, din ve vicdan hürriyetini haiz esaslar üzerine olmalıdır. Meslek kanunu içeriğinde öğretmenlik mesleki etik davranışları titiz bir şekilde detaylı olarak ve tartışmalara imkân vermeyecek şekilde yer almalıdır (ÖĞ-DER, 2019, $8-10)$.

\subsection{Disiplin İşlemleri}

TEDMEM'e göre öğretmenlere davranışlarının niteliklerine göre (TEDMEM, yty, 28-30):
a) Uyarı,
b) Kinama, 
c) Ders ücreti kesilmesi,

ç) Maaş kesilmesi,

d) Kademe ilerlemesinin durdurulmas1,

e) Meslekten çıkarma,

f) Devlet memurluğundan çıkarma, cezaları verilir.

Öğrencilere verilen ödev, görev, proje ve öğretim programı gereği takibi gereken çalışmaları kontrol etmemek ve gerekli düzeltmelerin yapılmasını temin etmemek; öğrencilerin devamdevamsızlığı ile ilgili kontrolleri yapmamak ve devamsızlık halinde okul idaresine zamanında bilgi vermemek, uyarı ve kınama cezalarının verildiği hareketlere örnek verilebilir.

Kabul edilebilecek mazereti olmadan derse girmemek veya girdiği halde dersten başka bir şeyle meşgul olmak, öğretmenler Kurulu ile ilgili mevzuatı gereği okulda oluşturulan kurul ve komisyon toplantı ve çalışmalara mazeretsiz olarak devam etmemek, bir ay zarfında iki defadan fazla derse geç gelmek ders ücretlerinin kesilmesi cezasının verildiği durumlardan gösterilmiştir.

Eğitim-Bir-Sen bu konuda ayrıntıya girmemiş, öğretmenlik mesleğine özgü disiplin suç ile cezaları, farklı ve afaki yorumlara sebebiyet vermeyecek bir açıklıkta, net ve kesin olarak belirlenmesini istemiştir (EBS; yty, 17).

ÖĞ-DER, meslek kanununda meslekten çıkarılma ile memurluktan çıkarılma hususları çok iyi tefrik edilmesini ileri sürmektedir. Ayrıca meslek kanunu, öğretmen hakkında açılan adli ve idari davalarla disiplin işlerinde hukuki yardım durumunu düzenlemelidir (ÖĞ-DER, 2019, 9$10)$.

\subsection{Eğitim Öğretim Hizmetleri Sınıfında Fiili Olarak Görev Yapanlara Karşı İşlenen Suçlarda Ceza Artırımı}

TEDMEM eğitim öğretim hizmetleri sınıfında görev yapanlara karşı, görevinden dolayı veya görevi ile ilişkili olarak, eğitim öğretim hizmetleri sınıfında görev yapanlar veya bunlar dışındaki kişilerce işlenen her türlü suçta cezanın bir kat artırılmasını istemektedir (TEDMEM, yty, 30). 
Eğitim-Bir-Sen, eğitim ve öğretim hizmeti esnasında veya verilen eğitim ve öğretim hizmetinden kaynaklanan nedenlerle cebir, şiddet veya tehdit kullanan kişilere karşı alt sınırı iki yıldan başlayan hapis cezası getirilmesini önermektedir (EBS; yty, 23).

ÖĞ-DER de bu konunun meslek kanununda olmasını ve ceza artırımı istemektedir (ÖĞ-DER, 2019, 9).

\section{SONUÇ}

Türk eğitim sisteminde öğretmenlik mesleğinin; öğretmen sendikaları, maaşların azlığı, öğrenci seçimi, akreditasyon, öğretmen adaylarının eğitimi, sözleşmeli-kadrolu olma ayrımı, mesleğin profesyonelleştirilmesi, öğretmen istihdamı, kamu personeli seçme sınavı, tayin isteme gibi birçok sorunla karşı karşıya olduğu bir gerçektir (Aynal Kilimci, 2011, 129; Çelebi, 2015, 136; Şimşek, 2019, 264; Yüksel, 2011, 111; Tuna, 2021, 122).

Türk eğitim sisteminde öğretmenler, hakları güvence altına alınması gereken temel bir öğedir. $\mathrm{Bu}$ güvence uzun süredir gündemde olan Öğretmenlik Meslek Kanunu'nun çıkarılması ile mümkün görünmektedir. Milli Eğitim Bakanlığı bu konuda taslak hazırlamış, kamuoyu ile paylaşacağını duyurmuş, eğitim sendikaları ve diğer ilgililer meslek kanunu için öneriler getirmişlerdir (Tuna, 2021, 122).

TEDMEM'in önerilerinde eğitim öğretim süreçlerinin merkezde olduğu görülmektedir. Bakanlığın üniversitelerle sıkı bir işbirliği yapması istenmiş, kanun öneri metni ayrıntılı ve sistemli olarak hazırlanmış, bütün maddeler gerekçelendirilmiştir. Eğitim-Bir-Sen'in önerileri ise öğretmen merkezlidir. Eğitim öğretim süreçlerinde öğretmenlerin daha belirleyici olması, sendikalara daha fazla söz hakkı verilmesi gerektiği vurgulanıyor. Metinde ayrıntıya girilmemiş, genel çerçeve çizilmeye çalışılmıştır. ÖĞ-DER'in önerileri süreç ve sonuç ağırlıklı olup, kısa ve öz öneriler sunulmaktadır. CHP’nin önerileri ise öğretmen ağırlıklı olup, detaylı, kapsayıc1, yeni çözümler getirici niteliktedir.

Tespit edilen ortak noktalar temel olarak şu şekilde sıralanabilir:

- Öğretmenlik, profesyonel bir meslektir.

- Öğretmenlik Meslek Kanunu paydaşlar için bir ihtiyaçtır. Kanun çıkarılmalıdır.

- Mesleki standartlar belirlenmiş olmalıdır. 
- Öğretmen adayları yükseköğretim programlarında yetiştirilir.

- Öğretmen adaylarının yetiştirilmesinde uygulamaya önem verilir.

- Öğretmenler kadrolu olarak atanmalıdır.

- Öğretmen adayları öğretmenliğe alınırken sınava tabi tutulmalıdır.

- Öğretmen adayı mesleki uyum /staj sürecini danışman öğretmen rehberliğinde tamamlamalidır.

- Eğitim kurumu yöneticileri, müfettişler kadro unvanına sahip olmalıdır.

- Yönetici adayları eğitime tabi tutulmalıdır.

- Öğretmenin mesleki gelişimi için her türlü imkân hazırlanmalıdır.

- Kariyer basamaklarında yükselmeler nesnel ölçütlere dayanmalıdır.

- Öğretmenler, dezavantajlı çalışma şartları gözetilerek ücret almalıdır.

- Öğretmenlere karşı işlenen suçların cezaları ağırlaştırılarak verilmelidir.

\section{KAYNAKÇA}

Aynal Kilimci, S. (2011). Türkiye'de Öğretmen Olmak. Türkiye’de Öğretmen Yetiştirme. (Editör: S. Aynal Kilimci). Ankara: Pegem Akademi Yayınları, 117-133.

Büyüköztürk, Ş., Çakmak Kılıç, E., Akgün, Ö.E., Karadeniz, Ş. ve Demirel, F. (2013). Bilimsel Araştırma Yöntemleri. Ankara: Pegem Akademi Yayıncılık.

Cumhuriyet Halk Partisi. (2018). Öğretmenlik Meslek Kanununa İlişkin Kanun Teklifi. 23.11.2018 tarih ve 421 say1l. https://www.chp.org.tr/yayinlar/bilim-platformu-yayinlari adresinden 20.06.2020 tarihinde alınd1.

Çelebi, N. (2015). Bir Meslek Olarak Öğretmenlik. Öğretmenlik Mesleğine Giriş. (Editör: A. Bakioğlu). Ankara: Nobel Akademik Yayıncılık, 115-145.

Eğitim Bir-Sen. (yayın tarihi yok). Araştırmalar. Eğitim- Bir-Sen: https://www.ebs.org.tr/ebs_files/files/yayinlarimiz/ogremenlik_meslek_kanunu_ihtiya c_oneriler.pdf adresinden 15.04.2020 tarihinde alınmıştır

Gülmez, M. (2010). Öğretmenlerin Statüsü Tavsiyesi (1966 ILO / UNESCO Ortak Belgesi). Ankara: Eğitim Sen Yayınları.

Karip, E. (2018). Öğretmenlik Meslek Kanunu Öneri Metni. Ankara: Tedmem Yayınları. 
Levent, A.F ve Övür Dönmez, M. (2019). Eğitim Hukuku. Ankara: Nobel Akademik Yayincilik.

Milli Eğitim Bakanlığı (2016). Sözleşmeli öğretmen istihdamına ilişkin yönetmelik. Resmi Gazete, 3 Ağustos 2016 tarih ve 29790 Sayıll.

http://www.resmigazete.gov.tr/eskiler/2016/08/20160803-22.htm. Erişim: 10.07.2019

MEB.

$(2020$,

Haziran

3).

2023

Eğitim

Vizyonu: http://2023vizyonu.meb.gov.tr/doc/2023_EGITIM_VIZYONU.pdf adresinden alınmıştır.

Sarpkaya, R. (2004). Bir Meslek Olarak Öğretmenlik. Öğretmenlik Mesleğine Giriş. (Editör: M. Gürsel ve M. Hesapçıŏlu). Konya: Eğitim Kitabevi, 63-96.

Şimşek, H. (2019). Öğretmenlik Mesleği ve Öğretmen Yetiştirmede Güncel Gelişmeler. Eğitime Giriş. (Editör: H. B. Memduhoğlu ve K. Yılmaz). Ankara: Pegem Akademi Yayıncılık, ss. 249-276.

Şuurlu Öğretmenler Derneği (2019). Öğretmenlik Meslek Kanunu Hakkındaki Düşünceler. Ankara. http://www.ogder.org/raporlar/meslekkanunu.pdf, adresinden 22.03.2021 tarihinde alınmıştır.

TEDMEM. (tarih yok). Yayınlar. TEDMEM: https://tedmem.org/download/ogretmenlikmeslek-kanunu-oneri-metni?wpdmdl=2925\&refresh=5ef389776cda11593018743 adresinden 11.04.2020 tarihinde alınmıştır.

Titrek, O. (2006). Öğretmenlik Mesleği. Eğitim Bilimine Giriş. (Editör: Ş.Şule ErçetinNecmettin Tozlu), Ankara: Hegem Yayınları, 311-338.

Topsakal, C. (2019). Policy on Teacher Employment Model in Turkey: Contracted Teachers. International Journal of Educational Methodology, vol.5, no. (November 2019), pp.671-682, 2019

Tuna, C. (2021). Öğretmenlerin Hakları ve Sorumlulukları. Eğitim Hukuku. (Editör: Tufan Aytaç). Ankara: Pegem Akademi Yayıncılık, ss. 99-124. 
Türk Dil Kurumu . (2020, Haziran 15). Güncel Türkçe Sözlük. Türk Dil Kurumu Sözlükleri: https://sozluk.gov.tr/ adresinden alınmıştır.

Yıldırım, A., Şimşek, H. (2006). Sosyal Bilimlerde Nitel Araştırma Yöntemleri. Ankara: Seçkin Yayınevi.

Yüksel, S. (2011). Türk Üniversitelerinde Ĕgitim Fakülteleri ve Öğretmen Yetiştirme. Ankara: Pegem Akademi Yayınları.

http://sinavlarnet.blogspot.com/2013/09/aof-adalet-bolumu-ders-kitaplari-indir.html adresinden 20.07.2021 tarihinde alınmıştır. 